\title{
HAK CIPTA DAN LISENSI YANG BERKAITAN DENGAN KONTEN ILMIAH TERMASUK HAK CIPTA TRADISI SERTA HAK MILIK BERSAMA DAN OPEN ACCESS
}

\author{
Islamiah Manurung \& Nur Afni Lubis \\ Fakultas Ilmu Sosial \\ Ilmu Perpustakaan Universitas Islam Negeri Sumatera Utara \\ Email: islamiahmanurung@gmail.com
}

\begin{abstract}
Abstrak
Journal open access merupakan Journal yang mampu disalurkan bagi setiap individu siapa saja dengan kebebasan serta tiada meminta anggaran sedikit pun. Oleh karena itu, dapat diartikan bahwa semua orang/masyarakat bisa mengakses secara bebas sesuai kebutuhannya masing-masing serta dapat dipergunakan kembali jika diperlukan. Sedangkan lisensi creative commons bahwasanya creative commons berpendapat bahwa lisensi creative commons menampilkan kesetaraan yang telah disepakati oleh hak cipta dengan membagikan tiap hasil karya ilmiah $\&$ hak cipta dari hasil karyanya. tantangan yang harus dihadapi oleh penerbitan model Open Access yaitu model pembiayaan dan kualitas penerbitan, dan hal lain yang menjadi tantangan penerbitan OA yaitu persoalan pelestarian atau penyimpanan arsip karya ilmiah. Dan salah satu layanan yang ditawarkan oleh penerbit komersial, selain distribusi artikel adalah pemeliharaan dan pelestarian.
\end{abstract}

Kata Kunci: Open Acess, Lisensi, Hak Cipta

\begin{abstract}
Open access journals are journals that are able to be distributed to any individual with freedom and do not ask for the slightest budged. Therefore, it can be interpreted that all people/communities can freely access according to their respective needs and can be reused if needed. Whereas the creative commons license states that the creative commons license displays the equivalence agreed upon by the copyright by sharing each work of scientific \& copyrighted works. Challengsh that must be faced by publishing the Open Access model, namely the financing model and the quality of publishing, namely the issue of preservation or storage of archivses of scientific papers. And one of the services offered by commoercial publishers, ini addition to article distribution is maintenance and preservation.
\end{abstract}

Keywords: Open Access, License, Copyright 


\section{Pendahuluan}

Istilah Open Access ini dimulai pada masa alat teknologi mulai dikenal yaitu pada tahun 1950 di Negara-Negara yang maju seperti Negara Amerika Serikat. Dengan demikian, Dimana Negara ini mereka sudah memanfaatkan teknologi elektronik atau online (jejaring) dengan menggunakan program tersendiri untuk menyimpan dan menelusuri informasi. Akses terbuka dalam memberikan informasi hal ini merujuk kepada koleksi bahan pustaka yang berbentuk digital yang sudah terpasang atau menggunakan koneksi internet yang tidak berbayar, serta memiliki kebebasan yang terikat kesemua gangguan hak cipta dari hasil karya tersebut. Sehingga dengan diadakannya karya ilmiah yang open akses atau tidak berbayar, maka para pengguna dapat memanfaatkannya dengan baik, untuk memenuhi segala kebutuhan informasi yang mereka harapkan.

Dari yang telah disebutkan diatas, disana telah memberitahukan betapa pentingnya karya ilmiah yang bersifat open akses dalam mencari informasi yang dibuthkan masyarakt, dengan disediakan oleh pihak perpustakaan atau instansi dengan berbagai informasi yang geratis, maka perpustakaan memiliki peran yang sangat kuat dan akan meningkatkan kemajuan atau institusi itu akan banyak dikenal orang/ternama.

\section{A. Definisi Akses Terbuka (Open Access)}

Dengan kemajuan Open access ini dimulai pada masa komputer mulai dikenal yaitu pada tahun 1950 di negara-negara berkembang seperti Amerka Serikat. Dimana negara ini sudah memanfaatkan teknologi elektronik atau online (terpasang) dengan menggunakan program khusus untuk menyimpan dan mencari informasi. Akses terbuka dalam memberikan informasi hal ini merujuk kepada koleksi bahan pustaka yang berbentuk digital 
yang sudah terpasang atau menggunakan koneksi internet yang tidak berbayar, serta memiliki kebebasan yang terikat kesemua gangguan hak cipta dari hasil karya tersebut.

Kemudian bisa dikatakan bahwa ada yang menyediakan berbagai ciptaan serta setiap karya ciptaan itu telah tersedia dan semua orang dapat mengutip dan mengakses hasil karya tersebut tanpa memiliki batasan-batasan. Open access (akses terbuka) pada hakikatnya biasa disingkat dengan OA, merujuk pada hasil karya ilmiah seperti melakukan penelitian, yang memberi kebebasan dari segala hal yang dapat membatasi semua akses. Dimulai dari biaya akses, dan terhindar dengan adanya larangan dalam memanfaatkan hasil karya ilmiah itu sendiri, (misalnya pembatasan hak cipta \& surat izin yang sangat terbatas).

Pengaksesan hasil karya ilmaih yang bersifat open access ada kalanya mampu diambil melewati pelunasan dari anggaran dalam memproses hal ini biasanya dalam masalah pembayaran itu ditanggung institusi peneliti untuk membuka aksesnya terhadap para pembaca, sehingga membuatnya 'terbuka' pada berbagai tingkat. Praktik akses terbuka dengan APC hal ini biasa dikenal dengam Gold Open Access ( akses terbuka emas).

1. Hal-hal mengenai akses terbuka

Pada dasarnya open acces memiliki kaitan antara dua macam, yaitu eksistensi technology yang canggih serta dapat diakses kedalam artikel, journal ilmiah yang berbentuk elektronik atau online. Pendit berpendapat bahwa Open Access selalu menyatakan pada daftar bacaan dimana telah disediakan dalam bentuk digital/online, geratis dan tidak terbatas dari semua ikatan atau hak cipta dan lisensi. Dengan demikian dapat dikatakan bahwa perpustakaan dapat memberikan informasi dan pengetahuan yang telah dilahirkan oleh lembaga secara khusus untuk membentuk 
institusi repository dengan memberikan akses terbuka / bebas kepada siapapun dan dimana pun serta dengan kebijakan dari lembaga atau instansi nya masing-masing. ${ }^{18}$

2. Open Access \& Licenses Creative Commons

Suber berpendapat mengenai open access jurnal, bahwa Journal open access merupakan Journal yang mampu disalurkan bagi setiap individu siapa saja dengan kebebasan serta tiada meminta anggaran sedikit pun. Oleh karena itu, dapat diartikan bahwa semua orang/masyarakat bisa mengakses secara bebas sesuai kebutuhannya masing-masing serta dapat dipergunakan kembali jika diperlukan. Sedangkan lisensi creative commons bahwasanya creative commons berpendapat bahwa lisensi creative commons menampilkan kesetaraan yang telah disepakati oleh hak cipta dengan membagikan tiap hasil karya ilmiah $\&$ hak cipta dari hasil karyanya.

Oleh karena itu, maka creative commons tidak berbeda pendapat dari hak cipta akan tetapi searah dengan hak cipta tersebut. Maka dari itu, licenses creative commons dapat didefinisikan sebagai sebuah penyokong dari hak cipta itu sendiri, hak cipta disini tidak mempunyai ketegaran dari ketentuanketentuan serta tidak akan memerlukan anggaran hak cipta, walaupun demikian hak cipta secara statis akan dimiliki oleh sipengarang journal tersebut. 19

Ada beberapa penyokong Open Access bahkan terjadi perselisihan tentang tata cara mana yang lebih utama mencapai tujuan OA. Ada dua tantangan yang harus dihadapi oleh

\footnotetext{
${ }^{18}$ Saufa Faila, Arina \& Hidayah, Nurrohmah, Open Access Dan Perpustakaan Digital, Tentang Perpustakaan Dan Mengelola Repository diPerguruan Tinggi, Yogyakarta: Universitas Islam Negri Sunan Kalijaga, 2018 Vol 10 No 1, Hlm 117

${ }^{19}$ Lona Windiana, Pengetahuan Konsep Lisensi Creative Commons Dan Open Access Di
} Kalangan Pengelola Situs E-Journal Semarang: Unip Tembalang, hlm 6 
penerbitan model Open Access yaitu model pembiayaan dan kualitas penerbitan, dan hal lain yang menjadi tantangan penerbitan OA yaitu persoalan pelestarian atau penyimpanan arsip karya ilmiah. Dan salah satu layanan yang ditawarkan oleh penerbit komersial, selain distribusi artikel adalah pemeliharaan dan pelestarian.

Open Access sebenarnya telah telahada pada sejak berkembangnya penggunaan internet di dunia, namun istilah Open Access ini telah dipopulerkan pada tahun 2002. Open Access ini resmi didefinisikan sebagai literatur atau sumber referensi digital dan lisensi.

Perkembangan Open Access Indonesia sudah mulai menggeliat di seluruh Indonesia termasuk di perguruan tinggi, dan institusi repositori yang berada pada puncak peringkat maknanya yaitu memiliki perhatian global yang lebih tinggi dibandingkan repository institusi yang lain. Repository institusi merupakan media yang telah berkembang lebih dulu sebagai alat desiminasikarya ilmiah institusi. Munculnya peringkatan kurang signifikan, dampak pada rasio jumlah perguruan tinggi yang terindeks dengan jumlah repositori institusi. 20

Banyak sekali keuntungan dengan adanya gerakan Open Access. Hal ini bisa dikelompokkan kedalam kategori sebagai berikut:

1. Penulis (authors), memberikan dampak yang lebih besar. Misalnya: membantu mencegah plagiat (helps guardagainst plagiarisme), visibilitas (visibility), hak cipta penulis, pemberian penghargaan kepada penulis dalam bentuk pengutipan, komunikasi ilmiah meningkat, paparan internasional, maupun pengakuan ilmiah.

${ }^{20}$ Yanuar Yoga Prasetyawan, Perkembangan Open Access dan Kontribusinya Bagi Komunikasi Ilmiah Indonesia, 2017, Semarang: Copyright Hlm 
2. Peneliti (researchers). Menyediakan pusat arsip pekerjaan peneliti, memudahkan penemuan dan penelusuran informasi ilmiah, memudahkan penyebaran informasi hasil penelitian, meningkatkan dampak dari penelitiannya, memungkinkan peneliti dapat mengetahui topik penelitian yang pernah dilakukan, dapat mengetahui tingkat pencapaian penelitian, maupun mengetahui tema penelitian yang masih belum tersentuh.

3. Lembaga (institutions). Tercapainya biaya penerbitan dan operasional penggunaan, membantu lembaga pendanaan dengan menyediakan akses publik ke hasil penelitian yang didanai publik, meningkatkan visibilitas dan prestise kepada badan pendanaan dan komunitas riset global, sebagai alat bantu dalam latihan penilaian penelitian.

4. Pembaca (readers) atau Pemustaka (users). Suatu contoh: pemustaka akses melalui Wikipedia dan tahu informasi yang tersedia tidak selalu akurat, lalu bisa link ke peer-review atau yang lainnya. Nah pada diskusi Open Access memainkan peran disini karena biasanya pembaca hanya cenderung bersandar kepada informasi yang tersedia secara bebas. Intinya dapat memberikan pembaca atau pemustaka akses bebas hambatan bagi literatur yang mereka butuhkan dengan aksesibilitas secara maksimal.

5. Masyarakat umum (public society). Memungkinkan akses ke temuan penelitian (access to research findings) secara lebih bebas dan mudah.

6. Perpustakaan (library), menegakkan biaya langganan yang tinggi sehingga perpustakaan. Dan tidak perlu melanggan, aksesibilitas lebih mudah, dapat melayani kebutuhan pemustaka yang sangat heterogen, menjadi solusi adanya aturan perijinan untuk akses. 
7. Pustakawan (librarian). Berpeluang dalam kajian Bibliometric, misalnya: sitasi (citations).

8. Pengajaran dan pembelajaran (teachingandlearning). Membantu seluruh siswa dan mahasiswa untuk akses materi yang sama dengan lebih mudah. OA memungkinkan mereka untuk mendapatkan informasi secara cepat, dan terkadang malah lebih dahulu daripada guru atau dosennya. Adanya media sosial akan memainkan peran penting dalam berinteraksi dengan konten Open Access. ${ }^{21}$

\section{B. Sumber-sumber hak cipta dalam komunikasi ilmiah}

Menurut pandangan Henry C.Black bahwasanya hak cipta itu dapat diartikan bahwa sebagai perlindungan dimana perlindungan ini tidak hanya berdasarkan hukum secara tertulis namun termasuk juga sebagai hukum yang tidak tertulis, dimana ia memiliki harapan serta keyakinan terhadap suatu benda yang dimiliki dalam melaksanakan hak serta kewajibannya. ${ }^{22}$

Terdapat didalam UU No. 28 tahun 2014 dimana mereka telah memberi batasan-batasan tentang hak cipta, pencipta, ciptaan, pemegang hak cipta (Bab I ayat 1 angka 1-4), yang dapat disebutkan sebagai berikut:

a. Bahwa hak cipta dapat didefinisikan sebagai sebuah hak atau yang memiliki kekuasaan dari pencipta yang muncul secara tersendiri, hak ini harus sesuai dengan prinsipprinsip pengumuman setelah penciptaan telah diwujudkan kedalam bentuk yang logis tanpa harus mengurangi

${ }^{21}$ Endang, Fatmawati, Gerakan Open Access Dalam Mendukung Komunikasi Keilmuan, 2013 Semarang: Vol.15 No 2

${ }^{22}$ Kusmawan, Denny, 2014, Perlindungan Hak Cipta Buku, Surabaya: Vol. XIX No.2 Program Studi Magister Sains Hukum dan Pembangunan Universitas Airlangga Surabaya, Hlm 138 
batasan-batasan sesuai dengan ketetapan/ketentuan yang berlaku dari UU itu sendiri.

b. Kemudian pencipta ini dapat diartikan bahwa satu orang / banyak orang dengan cara individu/berkelompok yang dapat mencetuskan suatu hasil karya yang bersifat pribadi atau khusus, bukan bersifat universal. Setelah itu ada namanya ciptaan, hal ini merupakan dari proses sebuah hasil ciptaan yang terdapatdi bidang pengetahuan, hasil karya (seni), tulisan (sastra) dan yang dihasilkan atas dasar dorongan dari, kemahiran, hasil analisis, khayalan atau angan-angan, serta keahlian yang diekspresikan dalam bentuk yang nyata.

c. Kemudianada yang namanya pemegang hak cipta, hal inidapat diartikan bahwa penciptaan sebagai seseorang yang pemilik hak cipta, sebuah pihak yang menerima hak tersebut secara sah dari pencipta itu sendiri, atau pihak lain yang menerima lebih lanjut hak dari pihak yang menerima hak tersebut secara sah. ${ }^{23}$

Ada empat sumber hak cipta dalam komunikasi ilmiah itu, antara lain:

1. Dilindungi / Dikendalikan

Dari sekian banyaknya hasil karya-karya ilmiah yang telah dicetuskan, semua hasil karya yang telah dicetuskan itu muncul sejak tahun 1978 adalah sebuah hasil karya yang telah dilindungi sebelum hasil karya itu disimpan atau dipaparkan kedalam bentuk-bentuk yang sistematis, termasuk hasil karya dalam penyimpanan pada bentuk kertas, filem atau diukir pada granit.

Pada hakikatnya, hak cipta tidak hanya berbentuk teks, melainkan iajuga berbentuk grafik, gambar, patung,

\footnotetext{
${ }^{23}$ Rumani, Sri, 2016 Hak Cipta, Open Access, Tinjauan Yuridis, Yogyakarta: Universitas Gaja
} Mada (UGM), Vol.5, No.2, Hlm 115 
karya arsitek, serta karya-karya ilmiah lainnya. Ada hukum baru dari dalam kongres telah memperluas perlindungan hukum, mencakup para pekerja yang mengkompilasi fakta tersebut, seperti yang dimiliki oleh database directive.Kemudian pada tahun 1989 hak cipta atau copyright.

Tidak diperlukan perlindungan, kenyataannya persayaratan sangat dipermudah pada tahun 1978. Setelah itu pada tahun 1978 pendaftaran pengawasan hak cipta telah menjadi pilihan, terkecuali untuk mendapatkan perlindungan dari perlanggaran pengrusakan dari hasil karya-karya tersebut.

2. Public Domain

Dalam hal ini public domain dapat diartikan sebagai hasil karya-karya yang tidak diawasi / dilindungi oleh hak cipta.dari hasil karya yang telah dipublikasikan.Hal ini dilakukan sebelum tahun 1978, hasil karya ini tidak ada hak ciptanya didaftarkan secara benar.Kemudian hasil karya yang telah dibuat oleh pemerintah dengan sebuah perjanjian yang berupa kontrak tidak bisa langsung dianggap sebagai public domain.Karya-karya public domain, dapat disalin secara keseluruhan atau universal dengan menggunakan web, atau mempublikasikannya tanpa izin pada pembayaran royalty.

Adapun sebuah contoh hasil karya public domain adalah Alkitab Versi King James, karya-karya Shakspeare, dan keputusan pengadilan atau kesepakatan. ${ }^{24}$

a. Fair Use

${ }^{24}$ Buxbaum, Shari, 2004, Library Service (Perpustakaan Virtual Untuk Kuliah Bisnis Jarak Jauh), Jakarta: PT Raja Gralindo Persada. HIm 25-29 
Pada hakikatnya Fair Use mempunyai makna hukum yang lebih spesifik. Dalam undang-undang hak cipta Amerika Serikat, mereka mengatakan bahwa Fair Use berdasarkan dengan empat kriteria, antara lain sebagai berikut:

1. Setiap pengguna memiliki tujuan dan sifat penggunaannya, disini termasuk apakah sifat penggunaannya dibuat untuk tujuan komersial atau untuk menunjang tujuan yang bersifat nirlaba.

2. Kemudian, karakter dari karya-karya yang mempunyai hak cipta itu sendiri.

3. Setelah itu, besarnya jumlah porsi yang telah digunakan sehubungan dengan penggunaan hasil karya-karya yang memiliki hak cipta tersebut secara universal atau keseluruhan.

4. Besarnya pengaruh penggunaan hasil karya terhadap nilai atau potensi dari hasil karya yang berhak cipta tersebut.

\section{Lisensi}

Sejarah singkat mengenai lisensi, berawal dari bahasa latin ialah licencia yang bermakna pengizinan/pembebasan. Dengan demikian, ketika seorang mengasikan terhadap para lisensi, oleh sebab itu, seorang tersebut mengasikan pembebasan atau memberikan pengizinan kepada orang tersebut untuk dimanfaatkannya, dimana yang awalnya tidak dapat dimanfaatkan. Sebagai contoh: dalam melakukan pendapatan dimana harus diawasi hak tersebut demi keuntungan produktif $\&$ induktif.

Oleh sebab itu, dengan tidak diadakannya lisensi, maka seorang yang terkait itu sendiri tidak memiliki kebebasan untuk dapat memanfaatkan dari hasil temuan tersebut, karena yang 
punya hak tidak dimengakui \& diawasi oleh UU. Selanjutnya, kata lisensi dapat diartikan secara hukum ialah sesuatu kesepakatan antara kedua belah pihak yaitu sipemberi dan sipenerima lisensi itu sendiri, yang mana lisensor bersama bayaran \& situasi tersebut dengan mengasikan pengizinan terhadap lisensi supaya dapat dimanfaatkan "intellectual property right" yang biasa disingkat dengan (HKI).

Yang dimaksud dengan lisensi sebuah pengizinan yang telah diberikan terhadap seorang atau lebih dengan cara serentak kepada hukum atau lembaga penguasa untuk menyajikan, memanfaatkan, memperdagangkan serta sebagai pemprosesan, dimana pengizinan tersebut dapat dikasikan dapat dilakukan oleh sebuah pihak yang berwenang dengan memiliki hak supaya bisa melaksanakan perlakukan itu sendiri.

Lisensi telah disepakati oleh dua pihak dimana sebuah karya yang berlisensi disini dapat diartikan sebagai sebuah hasil karya yang telah disepakati dalam sebuah perjanjian yang mengikat mereka dalam ketentuan-ketentuan yang menyampingkan fair use atau dengan pengecualian lain dari hukum itu sendiri.

Dengan adanya akses terbuka, jurnal LIS bisa mengadopsi atau mengambil lisensi (Creative Commons) http://www.creativecommons.org, Creative Commons untuk mendistribusikan konten. Seperti tingkat adopsi yang tinggi lisensi cc mempunyai definisi sebagai tanda selamat datang untuk membebaskan konten dari sebuah peraturan hak cipta yang nyata. 25

a. Perbedaan model lisensi konten terbuka

Dalam hal ini dapat dilihat perbedaan yang muncul antara setiap lisensi. Dengan ini, "lisensi publik" biasa juga disebut

\footnotetext{
${ }^{25}$ Cahyono, Teguh Yudi, 2014, Jurnal Akses Terbuka Dalam Ilmu Perpustakaan
}

Dan Informasi, Malang: Alih bahasa karya Shamprasad M. Pujar, Vol. 61, pp. 199-202. Hlm 7 
dengan lisensi konten terbuka dapat dialihkan kedalam bentuk lisensi yang standar dengan mengizinkan untuk penerimaan lisensi untuk menyebarkan, yang menyediakan untuk orang banyak atau terbuka. Dengan demikian, lisensi ini juga dapat diproduksi secara berulang-ulang dari hasil karya ilmiah dengan tujuan tidak untuk mendapatkan keuntungan dari sang penulis, dengan cara seperti apapun itu maka tidak akan mengenakan biaya atau anggaran sedikit pun.

Dengan demikian, lisensi publik memperluaskan dengan cara memperbolehkan, contohnya menciptakan dan menyebarluaskan hasil karya cipta secara turunan yang memperbolehkan kepentingan keuntungan pembelian dan penjualan karya tersebut. Adapun perbedaan antara berbagai lisensi ialah untuk membentuk ciptaan turunan dengan cara menyebarluaskan dengan menggunakan hasil dari ciptaan untuk kepentingan (komersial). 26

b. Manfaat menggunakan lisensi publik (lisensi konten terbuka)

Dalam menggunakan lisensi publik ada beberapa manfaat atau keuntungan yang dimiliki antara lain, dapat menyebarkan hasil ciptaan yang lebih universal, kemudian lisensi ini juga dapat mengingatkan kepastian hukum hak cipta bagi para pengguna secara signifikan dapat mengurangi biaya yang berhubungan dengan hukum.

c. Gaya/model-model Lisensi

Creative commons adalah sebuah tanda yang menunjukkan selamat datang untuk membebaskan karya ilmiah dari peraturan

${ }^{26}$ Till Kreutzer, 2011 Konten Terbuka Pedoman Praktis Penggunaan Lisensi Creative

Commons Jakarta: Wikimedia, hlm 15 
hak cipta yang kompleks. Dengan tersedianya open acces, journal LIS telah mengadopsi lisensi CC (Creative Commons), (http://www.creativecommons.org) dengan tujuan untuk menyebarluaskan karya ilmiah dengan membolehkan pengguna menyesuaikan dan menyalurkan karya ilmiah. Dengan demikian, terdapat beberapa faktor mengenai kebebasan/hak yang telah diberikan perlindungan seperti tidak ada sitasi untuk mempromosikan, dengan ini tidak akan digunakan untuk tujuan diperdagangkan dan lain-lain.

d. Ketentuan untuk menggunakan lisensi publik (lisensi konten terbuka)

Dalam memberikan penentuan lisensi publik atau biasa disebut dengan lisensi konten terbuka, dalam memberikan lisensi harus mempunyai hak yang dibutuhkan untuk melisensikan hasil karya tersebut. Dengan syarat harus memegang hak eksklusif, dengan semua hak yang telah dilindungi oleh lisensi konten terbuka, dan non-eksklusif hak non-eksklusif ini bertugas untuk memberikan sebuah karya atau ciptaan kepada setiap orang yang berkepentingan dalam hal tersebut. Adapun alasan hukum lainn ialah, bahwasanya dalam memegang hak cipta dari hasil karya ilmiah dengan ini dapat memberikan sub-lisensi kepada semua orang. ${ }^{27}$

e. Macam-macam perjanjian lisensi

Kesepakatam lisensi mempunyai berbagai bentuk. Menurut pandangan Lee \& Davidson bahwa ada dua macam lisensi antara lain Exclusve \& Non Exclusive, sementara Dratler berpendapat lain bahwa perlisensi itu akan muncul karena antara lain:

${ }^{27}$ Ibid $15-16$ 
- Voluntary Licenses, hal ini merupakan perlisensi segera berlangsung berlandaskan gagasan atau ide \& timbulnya persetujuan dari bagian sponsor \& memperoleh lisensi tersebut.

- Non Voluntary licenses, adapun yang dimaksudkan disini ialah lisensi akan berlangsung dikarenakan tersedianya permohonan bagian yang membutuhkan licenses \& desakan untuk mendapatkan kemufakatan serta diakui oleh bagian berwajib, dimana hal ini telah disepakati serta tuntunan $\&$ prosedur telah ditentukan internal UU.

Licenses individual telah didukung oleh penulis (HKI) memindahkan hak dari beberapa hasil karya yang dipunyainya terhadap golongan aksptor, walaupun demikian konsisten memberi batasan hak yang lain dimana hak ini terdapat pada $H K I$ itu sendiri. Licenses Non eksklusif merupakan sebuah model dengan memberikan hak pendayagunaan hak yang dipunyai oleh seorang HKI. 28

\section{f. Isi perjanjian licence}

Adapun isi kesepakatan lisensi ialah, seluruh kesepakatan wajib mencakupi komponen-komponen awal kategori supaya bisa dilaksanakan sesuai dengan rencana yang telah disepakati. Sebuah kesepakatan license memiliki kaitan yang erat dengan tiap-tiap perorangan ataupun dewan kekuasaan sebagai topik dalam ketentuan yang memiliki daya tampung didalam melakukan kesepakatan yang mencukupi aktualisasi pengesahan dari setiap kelompok, dengan mempertimbangkan sebuah tata cara dengan memikirkan antara kelompok yang melingkupi ketentuan-

${ }^{28}$ Sulasno 2009 Lisensi Hak Kekayaan Intelektual (Hki) Dalam Perspektif Hukum Perjanjian Di Indonesia Jurnal Hukum Vol. 3 No.2, hlm 367 
ketentuan yang berkarakter legal dilakukan dengan mengimplemen didalam naungan ketentuan yang bersifat relevan.

Dalam kesepakatan license sekurang-kurangnya meliputi beberapa hal, antara lain:

1. Sebuah gagasan pokok/ide, dimana telah terlesensikan, misalnya mengasi \& mengambil, dengan adanya pertolongan dari pihak teknisi, bagian $\&$ hubungan yang mencakupi tipe lisense yang akan dikasikan seperti apa tipe lisensi yang bersifat terbatas atau tidak terbatas.

2. Cakupan daerah hukum yang talah mensepakati lisence yang memberikan persetujuan untuk melaksanakannya siapa yang akan dipilih.

3. Kemudian, masa batas-batasan yang telah disepakati, baik itu masa pengalihan dan penerimaan dalam bentuk materi. 29

4. Moral Rights

Kegiatan moral right memiliki pengertian yang sama dengan fair use hal ini sama-sama dapat diartikan sebagai hukum yang khusus, serta disebutkan didalam UU AS (undang-undang Amerika Serikat) "17 USC 106A". moral right ini hak ciptanya hanya bisa berlaku untuk seni visual. Moral right ini memiliki hak untuk menuntut asal usul suatu karya ilmiah, tuntutan ini dilakukan untuk mencegah kesalahanggapan atas sebuah hasil karya yang telah dirusak atau di ubah bentuk dari sebuah karya ilmiah tersebut.

Didalam UU Negara di Benua Eropa, moral righet ini hanya berlaku untuk hasil karya yang bersifat menyeluruh, seperti hasil karya-karya yang berbentuk teks, serta memasukkan lebih banyak

\footnotetext{
${ }^{29}$ Retna Gumanti, Perjanjian Lisensi Di Indonesia, Vol. 12 No. 1, Gorantalo: IAIN Sultan Amai, 2016 http://journal.iaingorontalo.ac.id/index.php/am, hlm 255
} 
hak, termasuk hak dalam hukum Jerman, kemudian hak untuk Menarik sebuah hasil karya yang mana si pencipta tidak lagi menyetujuinya. Disini moral right bukan hak penggunanya akan tetapi hak penciptanya.

\section{Prinsip-Prinsip Perlindungan Hukum Hak Cipta}

Dalam hal ini Prinsip perlindungan hukum hak cipta merupakan sebuah pengakuan hak, untuk merumuskan pelanggaran hak cipta. Yang dilakukan atas dasar mengambil hasil karya orang lain dan di publikasikan tanpa di rubah katakatanya sedikit pun.

Oleh Karena itu, dalam UUHC kebijakan atas dasar hak-hak pencipta itu terbagi menjadi dua macam: yaitu hak ekonomi dan hak moral.

a. Hak ekonomi, keterwujudan dalam perlindungan hukum atas hak ekonomi ini merubah ke dalam bentuk untuk menentukan jenis perbuatan yang dilarang serta sanksi/imbalan pidana yang telah diatur dalam UUHC. hak ini meliputi reproduction right (hak penggandaan), distribution right (hak penyebarluasan), adaptation right (hak adaptasi).

b. Hak moral, hak ini mempunyai arti bahwa hak yangtelah melekat pada pencipta, yaitu hak untuk senantiasa dicantumkan nama penciptanya dalam setiap ciptaannyaserta hak atas keutuhan ciptaannya terhadapperubahan isi maupun judul. Dengan kata lain hak moralini tidak bisa dialihkan kepemilikannya atau haknya seperti hakekonomi. 30

\footnotetext{
${ }^{30}$ Ibid, hlm 15
} 


\section{E. Pengaturan Hak Cipta Dan Hak Milik Bersama Dalam Penggandaan Buku}

Buku atau koleksi merupakan sebuah tulisan yang berbentuk cetak dalam kertas atau berupa yang lain kemudian dijadikan satu dengan melakukan penjilitan, maka dapat dilihat pada bagian mana saja yang kita butuhkan. Zaman sekarang ini, lazimnya koleksi-koleksi bahan pustaka memiliki cover sebagai alat penyokong yang berfungsi sebagai alat untuk mencegah kerusakan dibagian isinya, sehingga buku-buku tersebut nilainilai informasinya akan tetap terjaga, serta dapat dimanfaatkan oleh siapapun.

Undang-Undang Nomor 28 Tahun 2014 tentang Hak Cipta terkait larangan penggandaan buku belum berhasil terlaksana dengan baik, sebagaimana terlihat dari masih populernya penggandaan buku yang dilakukan, misalnya oleh mahasiswa dan pengelola usaha fotokopi (dengan motif untuk memperoleh keuntungan secara ekonomis). Perilaku seperti ini tentu harus mulai ditertibkan.

1. Aturan menggandakan koleksi bahan pustaka (buku)

Dalam penggandaan buku telah diatur dalam UU No. 28 Tahun 2014, mengenai Hak Cipta yaitu Pasal 47 huruf a dengan ini dinyatakan bahwa, di setiap perpustakaan atau lembaga kearsipan yang tidak memiliki tujuan komersial maka dapat membuat satu salinan ciptaan atau bagian ciptaan tanpa sepengetahuan dari pencipta atau yang mengontrol hak cipta itu sendiri. 31

\footnotetext{
${ }^{31}$ Prasetyo, 2017, Perlindungan Hukum Pencipta Atas Penggandaan Buku Ilegal Berdasarkan Undang-Undang Nomor 28 Tahun 2014 Tentang Hak Cipta (studi kasus penggandaan buku oleh pedagang buku Titi Gantung Medan), Medan: Universitas Sumatra Utara, hal 8
} 


\section{F. Pelaksanaan Hak Cipta Dengan Kemajuan Teknologi Informasi}

Seiring dengan maju dan berkembangnya teknologi informasi saat ini, kegiatan mengalihmediakan, serta mempublikasikan hasil karya ilmiah, untuk menyebarkan hasil tersebut dapat dilakukan oleh siapa saja dan dimana saja dengan mudahnya. Setelah melakukan penulisan, walaupun tulisan itu masih tahap awal, para penulis dengan mudahnya bisa meletakkan hasil karyanya disebuah situs web, ataupun yang lainnya.

Dengan tersedianya sarana ini, para penulis dapat meminta masukan mengenai karya ilmiahnya kepada para pembaca dengan berbagai bangsa serta disiplin ilmu apa saja. Setiap penulis dengan cepatnya merombak ulang hasil karya ilmiah yang telah dipublikasikan, kapan saja, tidak harus menunggu karya tersebut sampai beredar 1 thn lamanya misalnya seperti itu, atau bisa dikatakan jika karya tersebut cetakan pertamanya sudah habis dijual. Kemudian karya ilmiah tersebut dapat dimanfaatkan secara mudah oleh siapa saja dan dimana saja. ${ }^{32}$

\section{Hak Cipta Tetap Dipegang Oleh Sipenulis}

Seandainya hak cipta dipegang dan dikelola oleh penulis, maka inilah yang akan terjadi. Setiap kali ada orang yang ingin memperbanyak, mebagikan, dan mengubah(mengalih-media, menterjemahkan, mengadaptasi, suatu karya, dia harus menghubungipenulisnya. Syukur apabila penulis tersebut mudah dijangkau melalui e-mail atautelepon. Mengurus perijinan ini pastilah sedikit atau banyak, akan memakan waktu,apalagi kalau memerlukan paperworks. Kalau tidak berhasil menghubungi si penulis, maka pengguna akan (harus) memutuskan niatnya untuk

\footnotetext{
${ }^{32}$ Diao Ai Lien 1998, Hak Cipta Dan Penyebaran Pengetahuan, Jakarta, hlm 12-13
} 
memperbanyak, mendistribusikan, danatau mengubah karya tersebut. ${ }^{33}$

2. Hak cipta diproduksi menjadi hak moral

Adapun yang dimaksudkan dari perrnyataan diatas adalah sebuah ketetapan hak cipta dalam komunikasi ilmiah itu hanya mengenai hak moralnya saja. Oleh sebab itu, bahwasanya siapa pun itu berhak mengambil/mengutip, mendigitalisasikan, serta mempublikasikan sebuah hasil ciptaannya, selagi tidak bertujuan untuk forfitable. Oleh karena itu, garis pengedaran sebuah informasi harus lebih dipermudah dengan cara mengalihkan pengekangan dalam pengedaran hasil ciptaan dari penerbit ke pengarang \& seluruh masyarakat, serta dapat menyedikitkan reaksi penyebaran yang cukup lama \& anggaran dana yang cukup tinggi, kemudian penguasaan hak cipta dapat tersingkirkan.

Menurut pandangan Birdsall bahwasanya didalam perancangan open access terdapat "copyleft" yang artinya sekelompok licenses yang alokasikan pada sekumpulan orang yang mempunyai salinan hasil ciptaan akan dipertanggungjawabkan supaya setiap orang mampu melaksanakan aturan perniagaan dari hasil ciptaan itu sendiri, seperti dengan cara melakukan memperbanyak dan mempublikasikan hasil karya tersebut, serta ketentuan dari hasil ciptaan yang telah mempublikasikannya harus dengan licence yang serupa tidak boleh berbeda.

Dengan demikian, dalam ketentuan yang telah ditentukan bahwasanya Open Access diperbolehkan tidak Cuma berbentuk document digital saja melainkan berbentuk cetak. Oleh sebab itu, hak cipta bukan saja memberikan keuntungan secercah kepada

${ }^{33}$ Irawati, Implikasi Perubahan Status Penerima Lisensi Terhadap Perjanjian Lisensi Hak Cipta Pada Organisasi KSBSI, 2018: Semarang Vol. 14 No 2 
orang-orang khususnya penerbit pencetak dimana ia tidak termasuk kedalam pengarang, \& melambat-lambatkan partisipasi yang melimpah orang kepada pengarang dari ciptaannya. ${ }^{34}$

\section{G. Kegunaan Pendaftaran Hak Cipta}

Menurut pandangan Saidin, kegiatan prosedur pendataan hak cipta \& (HKI), biasanya diketahui ada 2 bentuk system, ialah system konsekutif \& system deklarasi. Adapun system konsekutif itu merupakan sebuah registrasi karya seseorang yang bertujuan akan menciptakan (hak cipta) tentang hasil karya tersebut. Dengan tidak melakukan registrasi, maka setiap orang yang menciptakan hasil karya ilmiah, tidak akan spontan memiliki hak yang berlandaskan dengan hak cipta dari hasil karyanya.

Pada dasarnya, hak cipta ini muncul sesudah pengarang melaksanakan registrasi \& berdampak pada registrasi yang telah mempunyai ketetapan secara otomatis. Saidin juga berpendapat bahwa kegunaan dari registrasi tentang system ini semata-mata demi membagikan sebuah prasangka, terkait dengan UU, seorang telah meregistrasikan sebuah hasil karya ilmiahnya itu merupakam seorang yang memiliki kebebasan berdasarkan hak cipta atas hasil karya ilmiahnya itu sendiri.

Dapat diartikan bahwa hak cipta adalah sebuah hak secara individual untuk pengarang dan penunjang dari hak cipta yang bertujuan akan mempromosikan dan melipatgandakan hasil karya ilmiahnya, yang akan muncul secara tersendiri selesai dari karya yang telah dicetuskan tidak akan menyusutkan kualifikasi menurut aturan-aturan yang telah berlaku untuk UU.

Adapun prinsip yang menyeluruh serta memiliki aturan-aturan yang terdapat didalam (Berne Convention for the Protection of Literary and Artistic Works) dengan hal ini yang ditetapkan dan

${ }^{34}$ Ibid, hlm 14-15 
disepakati oleh Presiden Republik Indonesia yaitu Nomor. 18 Thn 1997. Pasal 5 ayat 2, hal ini merupakan sifat-sifat hak cipta yang telah mencetuskan karya ilmiah secara tersendiri dengan tidak melakukan registrasi.

Dapat diartikan bahwa ketentuan dalam melindungi hak cipta tiada diperlukan hal-hal yang bersifat formal apa pun itu. Dengan kata lain, registrasi tidak dibenarkan menyajikan ketentuan yang telah ditetapkan untuk melakukan pengawasan, dengan demikian kegunaan registrasi terkait dengan hak cipta itu tidak harus bahkan beberapa Negara seperti Inggris, Australia, Malaysia, Jerman, Spanyol, Singapura serta Mesir. ${ }^{35}$

\section{H. Hak cipta \& Perpustakaan}

Menurut pandangan Heri Abi Burchman Hakim bahwa Library mengumpulkan \& memberi layanan bermacam tipe ciptaan yang telah diawasi dari hak cipta. Hak cipta disini berupa koleksi bahan pustaka, jurnal, majalah, artikel dan lain sebagainya, yang berfungsi seperti bentuk buku yang ada didalam Perpustakaan dimana didalamnya terdapat hak ciptanya. Oleh sebab itu, pada hakikatnya library memiliki kaitan yang sangat kuat bersama hak cipta. Dimana beraneka macam koleksi bahan pustaka yang terdapat diperpustakaan maka memerlukan perlindungan serta hak ciptanya akan diawasi oleh pihak Perpustakaan.

Kemudian pihak Perpustakaan harus berjaga-jaga secara nyata dalam memberikan layanan library malah akan berdampak besar akan menjadi acuan melanggar hak cipta yang telah ditetapkan. Kemudian uniknya library bisa dibuat sebagai contoh internal untuk mendirikan hak cipta $\&$ mensosialisasikan terkait hak cipta itu sendiri. Perpustakaan sekarang ini kebanyaan bahan

${ }^{35}$ Hesty D. Lestari 2013, Copyright Ownership In The License Agreement, Jakarta hal 179 
pustakanya sudah digital serta menyemaraknya plagiarisme dari hasil karya ilmiah yang artinya sebuah berita atau pelayanan library yang berkaitan kepada hak cipta.

Sebuah lembaga library harus menyediakan kualifikasi secara nyata terkait penyediaan layanan foto copy supaya layanan tersebut tiada dikategorikan sebagai model melakukan langgaran hak cipta. Dengan sudah digitalnya bahan pustaka, maka Perpustakaan ia harus berjaga-jaga supaya aktivitas yang dibuat tidak akan melampaui hak cipta dari ciptaannya. Oleh sebab itu, library juga harus membenahi plagiarisme koleksi bahan pustaka/karya ilmiah dengan bermacam-macam jenis \& tidak secara produksi bahan pustaka hingga tidak mampu disalurkan oleh user library. ${ }^{36}$

C.S.T. Kansil ia mengatakan bahwa hak cipta mempunyai makna yang terdapat didalam UU yang mengarah kepada yang punya hak cipta \& para pejabat/yang memegang hak cipta atau salah satu dari kedua tersebut. Dimana hal ini terdapat didalam UU Hak Cipta pada pasal (1) ayat 1 No.19 thn 2002, dengan hal ini mengatakan bahwa "hak cipta merupakan hak diskriminatif untuk pengarang/penerimaan hak cipta yang bertujuan untuk mempromosikan serta menggandakan hasil karyanya atau mempersilahkan pengesahan hal tersebut. Serta tidak menyurutkan pemisahan-pemisahan menurut tata aturan dalam UU yang berlangsung. ${ }^{37}$

\footnotetext{
${ }^{36}$ Ade Uswatun Sitorus , 2015, Hak Cipta Dan Perpustakaan, Jurnal Iqra' Volume 09 No.02 hlm 253

${ }^{37}$ Ibid hlm, 255
} 


\section{KESIMPULAN}

Akses terbuka dalam memberikan informasi hal ini merujuk kepada koleksi bahan pustaka yang berbentuk digital yang sudah terpasang atau elektronik, tidak berbayar serta serta memiliki kebebasan yang terikat kesemua gangguan hak cipta dari hasil karya tersebut. Kemudian bisa dikatakan bahwa ada yang menyediakan berbagai ciptaan serta setiap karya ciptaan itu telah tersedia dan semua orang dapat mengutip dan mengakses hasil karya tersebut tanpa memiliki batasan-batasan. Menurut pandangan Henry C. Black bahwa hak cipta itu dapat diartikan bahwa sebuah perlindungan tidak hanya berdasarkan hukum secara tertulis namun termasuk juga sebagai hukum yang tidak tertulis dimana ia memiliki harapan serta jaminan terhadap suatu benda yang dimiliki dalam melaksanakan hak dan kewajibannya.

Kemudian Open Akses terbuka telah membawa pandangan baru untuk penyebaran konten ilmiah.Hari ini, bidang konten ilmiah dalam berbagai bentuk didistribusikan secara online di internet, gratis dan bebas dari hak cipta dan pembatasanperizinanolehpenerbit, lembaga atau individu. Open access (OA) penting untuk negara-negara berkembang termasuk Indonesia. Semakin banyak literatur penelitian dengan akses terbuka, akan memberi manfaat lebih besar bagi umat manusia. Bagi negara berkembang seperti Indonesia OA menjadi lebih penting setidaknya karena dua hal. 


\section{DAFTAR PUSTAKA}

Ade Uswatun Sitorus , 2015, Hak Cipta Dan Perpustakaan, Jurnal Iqra' Volume 09 No.02 hlm 253

Buxbaum, Shari, 2004, Library Service (Perpustakaan Virtual Untuk Kuliah Bisnis Jarak Jauh), Jakarta: PT Raja Gralindo Persada. Hlm 25-29

Cahyono, Teguh Yudi, 2014, Jurnal Akses Terbuka Dalam Ilmu Perpustakaan Dan Informasi, Malang: Alih bahasa karya Shamprasad M. Pujar, Vol. 61, pp. 199-202. H1m 7

Diao Ai Lien 1998, Hak Cipta Dan Penyebaran Pengetahuan, Jakarta, hlm 12-13

Endang, Fatmawati, Gerakan Open Access Dalam Mendukung Komunikasi Keilmuan, 2013 Semarang: Vol.15 No 2

Hesty D. Lestari 2013, Copyright Ownership In The License Agreement, Jakarta hal 179

Irawati, Implikasi Perubahan Status Penerima Lisensi Terhadap Perjanjian Lisensi Hak Cipta Pada Organisasi KSBSI, 2018: Semarang Vol. 14 No 2

Kusmawan, Denny, 2014, Perlindungan Hak Cipta Buku, Surabaya: Vol. XIX No.2 Program Studi Magister Sains Hukum dan Pembangunan Universitas Airlangga Surabaya, Hlm 138

Lona Windiana, Pengetahuan Konsep Lisensi Creative Commons Dan Open Access Di Kalangan Pengelola Situs E-Journal Semarang: Unip Tembalang, hlm 6

Prasetyo, 2017, Perlindungan Hukum Pencipta Atas Penggandaan Buku Ilegal Berdasarkan Undang-Undang Nomor 28 Tahun 2014 Tentang Hak Cipta (studi kasus penggandaan buku oleh pedagang buku Titi Gantung Medan), Medan: Universitas Sumatra Utara, hal 8

Retna Gumanti, Perjanjian Lisensi Di Indonesia, Vol. 12 No. 1, Gorantalo: IAIN Sultan Amai, 2016 http://journal.iaingorontalo.ac.id/index.php/am, hlm 255

Rumani, Sri, 2016 Hak Cipta, Open Access, Tinjauan Yuridis, Yogyakarta: Universitas Gaja Mada (UGM), Vol.5, No.2, Hlm 115

Saufa Faila, Arina \& Hidayah, Nurrohmah, Open Access Dan Perpustakaan Digital, Tentang Perpustakaan Dan Mengelola Repository diPerguruan Tinggi, Yogyakarta: Universitas Islam Negri Sunan Kalijaga, 2018 Vol 10 No 1, Hlm 117

Sulasno 2009 Lisensi Hak Kekayaan Intelektual (Hki) Dalam Perspektif Hukum Perjanjian Di Indonesia Jurnal Hukum Vol. 3 No.2, hlm 367 
Till Kreutzer, 2011 Konten Terbuka Pedoman Praktis Penggunaan Lisensi Creative Commons Jakarta: Wikimedia, hlm 15

Yanuar Yoga Prasetyawan, Perkembangan Open Access dan Kontribusinya Bagi Komunikasi Ilmiah Indonesia, 2017, Semarang: Copyright Hlm 